\title{
DAMPAK COVID-19 TERHADAP MOTIVASI BELAJAR DARING PJOK SMP NEGERI 12 DENPASAR TAHUN PELAJARAN 2020/2021
}

\author{
I Made Nova Riadnya, I Putu Panca Adi, I Made Satyawan. \\ Jurusan Pendidikan Jasmani Kesehatan dan Rekreasi \\ Universitas Pendidikan Ganesha \\ Singaraja,Indonesia \\ e-mail: \{novariadnya@gmail.com, panca.adi@undiksha.ac.id , \\ made.satyawan@undiksha.ac.id \} @undiksha.ac.id
}

\begin{abstract}
ABSTRAK
Penelitian bertujuan untuk mengetahui dampak pandemi covid-19 terhadap motivasi belajar daring mata pelajaran PJOK peserta didik kelas VIII SMP Negeri 12 Denpasar tahun pelajaran 2020/2021. Penelitian diklasifikasian ke dalam penelitian eksperimen semu, dengan populasi adalah seluruh peserta didik kelas XIII SMP Negeri 12 Denpasar berjumlah 437 orang. Sampel adalah peserta didik kelas XIII F dengan jumlah 40 orang. Analisis data digunakan analisis statistik deskriptif. Hasil analisis data yang dilakukan mendapatkan rata-rata motivasi belajar PJOK peserta didik pada saat penerapan pembelajaran daring sebesar 63,8. Sementara itu dilihat dari distribusi nilai rata-rata motivasi belajar PJOK pada saat penerapan pembelajaran daring berada pada katagori rendah. Berdasarkan analisis statistik deskriptif yang digunakan untuk menguji hipotesis, maka hasil penelitian dapat disimpulkan, terdapat dampak pandemi covid-19 terhadap motivasi belajar daring mata pelajaran PJOK. Dampak yang dihasilkan adalah lebih rendahnya motivasi belajar PJOK peserta didik karena penerapan pembelajaran daring dari dampak pandemi covid-19.
\end{abstract}

Kata-kata Kunci : Covid-19, pembelajaran daring, motivasi belajar, PJOK

\begin{abstract}
The study aims to determine the impact of the Covid-19 pandemic on online learning motivation in the subjects of physical education, sports and health of class VIII students of SMP Negeri 12 Denpasar in the 2020/2021 school year. The research was classified into quasi-experimental research, with the population being all students of class XIII SMP Negeri 12 Denpasar totaling 437 people. The sample was 40 students of class XIII F. Data analysis used descriptive statistical analysis. The results of the data analysis carried out showed that the average motivation to learn physical education, sports and the health of students at the time of implementing online learning was 63.8. Meanwhile, seen from the distribution of the average value of learning motivation, physical education, sports and health at the time of implementing online learning were in the low category. Based on the descriptive statistical analysis used to test the hypothesis, the results of the study can be concluded that there is an impact of the Covid-19 pandemic on online learning motivation in sports and health physical education subjects. The resulting impact is a lower motivation to learn, physical education, sports and student health due to the application of online learning from the impact of the Covid-19 pandemic.
\end{abstract}

Key Words: Covid-19, online learning, motivation to learn, physical education, sports and health

\section{PENDAHULUAN}

Seiring dengan perkembangan zaman, semakin besar pula permasalahan yang dihadapai oleh setiap masyarakat. Permasalahan yang dihadapi oleh masyarakat sebagian besar berbeda antara masyarakat yang satu dengan masyarakat yang lain. Namun demikian tidak menutup kemungkinan satu masalah bisa dihadapi oleh banyak orang dan dalam waktu yang bersamaan. Berapa bulan belakangan ini dunia dihebohkan dengan adanya penyakit menular yang di namakan Covid-19.Covid19 adalah virus yang menyerang sistem pernapasan. Penyakit karena infeksi virus ini disebut Covid-19 dan populer di 
Indonesia dengan nama virus Corona.Penularan sangat cepat hingga Organisasi Kesehatan Dunia WHO menetapkan pandemi Covid-19 pada 11 Maret 2020.

Pandemi atau epidemi global mengindikasikan infeksi Covid-19 yang sangat cepat hingga hampir tak ada negara atau wilayah di dunia yang absen dari Covid-19. Peningkatan jumlah kasus terjadi dalam waktu singkat hingga butuh penanganan secepatnya. Sayangnya, hingga kini belum ada obat spesifik untuk menangani kasus infeksi Covid-19. WHO menyatakan saat ini Eropa telah menjadi pusat pandemi Covid-19 secara global.Eropa memiliki lebih banyak kasus dan kematian akibat Covid-19 dibanding Cina. Sementara itu di Indonesia, Covid-19 pertama kali terdeteksi pada awal bulan Maret tahun 2020, tepatnya pada tanggal 2 Maret 2020.

Penyebaran Covid-19 yang terjadi sangat cepat mengakibatkan dampak yang sangat besar bagi dunia Internasional, tidak terkecuali bagi Indonesia. Di Indonesia banyak sektor yang mengalami kelumpuhan akibat wabah Covid-19 mulai dari sektor pariwisata, sektor ekonomi sampai sektor pendidikan mengalami dampak yang sangat besar. Dari sektor pendidikan terutama pendidikan formal, dampak yang ditimbulkan adalah tidak bisa dilaksanakannya proses belajar mengajar secara normal atau melalui tatap muka langsung yang dilaksanakan di sekolah. Hampir seluruh sekolah diliburkan sejak merebaknya wabah tersebut. Kegiatan belajar mengajar yang biasanya menjadi pemandangan yang lumrah setiap harinya seketika lenyap. Terdampaknya sektor pendidikan merupakan kerugian yang sanagt besar, karena pendidikan merupakan suatu unsur yang tidak dapat dipisahkan dan diri manusia.

Pendidikan merupakan faktor penting bagi masyarakat, demi maju mundurnya kualitas masyarakat atau bangsa sangat bergantung pada pendidikan yang ada pada rakyat bangsa tersebut. Pendidikan akan memberikan dampak positif bagi para generasi muda dan juga pendidikan akan meyiapkan generasi yang baik dan bagus bagi Negaranya. Maka dari itu para pendidik harus membutuhkan keuletan dan kesabaran dalam mengajarnya.

Pembelajaran yang seyogyanya dilaksanakan secara tatap muka di kelas maupun lingkungan sekolah seketika diubah oleh pemerintah dengan menerapkan sistem pembelajaran jarak jauh atau melalui pembelajaran daring/online. Dengan tidak dilaksanakannya proses pembelajaran secara tatap muka, mengakibatkan proses pembelajaran tidak berlangsung secara maksimal. Hal tersebut akan berpengaruh pada hasil belajar yang diperoleh peserta didik di semua mata pelajaran, tidak terkecuali mata pelajaran pendidikan jasmani olahraga dan kesehatan (PJOK).

Pendidikan jasmani olahraga dan kesehatan merupakan mata pelajaran yang wajib diberikan secara formal. Mata pelajaran PJOK secara garis besar lebih menekankan praktek dibandingkan teori, jadi dengan demikian proses pembelajaran yang dilaksanakan seharusnya bisa dilaksanakan secara langsung atau melalui tatap muka antara guru dengan peserta didik. Dalam hal belajar peserta didik akan berhasil kalau dalam dirinya sendiri ada kemauan untuk belajar dan keinginan atau dorongan untuk belajar, karena dengan peningkatan motivasi belajar maka peserta didik akan tergerak, terarahkan sikap dan perilaku peserta didik dalam belajar.

Berdasarkan uraian di atas dan melihat situasi pendidikan yang seakan terlihat terpuruk akibat merebaknya wabah Covid-19, maka penulis berkeinginan untuk mengangkat suatu penelitian dengan judul "Dampak Pandemi Covid-19 Terhadap Motivasi Belajar Daring Mata Pelajaran 
Pendidikan Jasmani Olahraga dan Kesehatan Peserta DidikKelas VIII SMP Negeri 12 Denpasar Semester Ganjil Tahun Pelajaran 2020/2021".

\section{KAJIAN TEORI}

COVID-19 merupakan keluarga besar virus yang menyebabkan penyakit pada manusia dan hewan. Pada manusia biasanya menyebabkan penyakit infeksi saluran pernapasan, mulai flu biasa hingga penyakit yang serius seperti Middle East Respiratory Syndrome (MERS) dan Sindrom Pernafasan Akut Berat/Severe Acute Respiratory Syndrome (SARS). COVID-19 jenis baru yang ditemukan pada manusia sejak kejadian luar biasa muncul di Wuhan Cina, pada Desember 2019, kemudian diberi nama Severe Acute Respiratory Syndrome Coronavirus 2 (SARS-COV2), dan menyebabkan penyakit Coronavirus Disease-2019 (COVID-19). Gejala umum berupa demam $\geq 38^{\circ} \mathrm{C}$, batuk kering, dan sesak napas. Jika ada orang yang dalam 14 hari sebelum muncul gejala tersebut pernah melakukan perjalanan ke negara terjangkit, atau pernah merawat/kontak erat dengan penderita COVID-19. Di Indonesia penyebaran COVID-19 mulai terjadi pada tanggal 2 Maret 2020. Presiden Joko Widodo mengumumkan secara resmi kasus pertama COVID-19 di Indonesia di Istana Negara tanggal 2 Maret 2020. Rumitnya penanganan wabah ini membuat para pemimpin dunia menerapkan kebijakan yang super ketat untuk memutus rantai penyebaran COVID-19. Sosial distancing menjadi pilihan berat bagi setiap negara dalam menerapkan kebijakan untuk pencegahan penyebaran COVID-19, karena kebijakan ini berdampak negatif terhadap segala aspek kehidupan. Kebijakan sosial distancing berakibat fatal terhadap roda kehidupan manusia, masalah ekonomi yang paling terasadampanya, selain itu bidang pendidikan ikut juga terdampak kebijakan ini, Keputusan pemerintah yang secara mendadak meliburkan atau memindahkan proses pembelajaran dari sekolah menjadi kegiatan belajar di rumah, membuat kelimpungan banyak pihak. Pemindahan proses pembelajaran dari sekolah ke rumah secara mendadak membuat stakeholder sekolah tidak siap.

Belajar adalah proses perubahan perilaku berkat pengalaman dan latihan. Artinya tujuan kegiatan adalah perubahan tingkah laku, baik yang menyangkut pengetahuan, keterampilan, maupun sikap, bahkan meliputi segenap aspek pribadi. Gagne (dalam Susanto, 2013: 1) menyatakan, "belajar dapat didefinisikan sebagai suatu proses di mana suatu organisme berubah prilakunya sebagai akibat pengalaman. Hamalik (2001: 28), menyatakan bahwa, " belajar merupakan suatu proses perubahan tingkah laku individu melalui interaksi dengan lingkungan".

Dalam pendidikan formal proses belajar menjadi satu konsep yang tidak dapat terpisahkan dengan mengajar. Dua konsep ini menjadi terpadu dalam satu kegiatan di mana terjadi interaksi antara peserta didik dengan guru, serta peserta didik dengan peserta didik yang dimaksud dengan pembelajaran. Menurut Susanto (2013) menyatakan, "pembelajar0an merupakan perpaduan dari kegiatan belajar dan mengajar". Aktivitas belajar secara metodologis cenderung lebih dominan pada peserta didik, sementara mengajar secara instruksional dilakukan guru.

Belajar dalam PJOK pada dasarnya berhubungan dengan kesanggupan seseorang untuk menggerakkan anggota badan. Namun, peserta didik bukan hanya menggerakkan anggota badan melainkan juga memerlukan keterampilan sikap dan intelektual. Oleh karena itu, bagi seseorang yang ingin mempelajari keterampilan gerak terlebih dahulu harus memahami dan 
menguasai prosedur gerakan yang dilakukan disertai konsep cara-cara melakukannya. Di dalam program pengajaran PJOK, setiap bentuk bahan pelajaran keterampilan gerak biasanya memiliki urutan gerak yang harus dilakukan dengan cepat, tepat, luwes, dan lancar.

$$
\text { Kaitannya dengan proses }
$$

pembelajaran, bahwa pembelajaran itu merupakan suatu kegiatan yang bernilai edukatif. Nilai edukatif mewarnai interaksi yang terjadi antara guru dan anak didik yang sengaja diciptakan untuk mencapai suatu tujuan pembelajaran. Pembelajaran merupakan suatu proses yang melibatkan interaksi antara guru dengan peserta didik dengan harapan mendapatkan pemahaman tentang apa yang diperoleh dalam situasi pembelajaran.

Berdasarkan pendapat di atas, yang dimaksud dengan pembelajaran ialah suatu proses interaksi guru dengan peserta didik dalam rangka pengembangan pengetahuan, keterampilan atau sikap baru pada saat peserta didik berinteraksi dengan informasi dan lingkungan untuk mencapai tujuan belajar tertentu. Tujuan pembelajaran hendaknya memenuhi kriteria situasi atau kondisi untuk belajar, rumusan tingkah laku, dan ukuran minimal tingkah laku yang diinginkan. Kunci dalam rangka menentukan tujuan pembelajaran adalah kebutuhan peserta didik, mata pelajaran, dan guru itu sendiri. Agar tujuan pembelajaran dapat tercapai, guru harus mampu mengorganisir semua komponen sedemikian rupa sehingga antara komponen yang satu dengan lainnya dapat berinteraksi secara harmonis. Salah satu komponen dalam pembelajaran adalah pemanfaatan berbagai macam strategi dan metode pembelajaran secara dinamis dan fleksibel sesuai dengan materi peserta didik dan konteks pembelajaran, sehingga dituntut kemampuan guru untuk dapat memilih model pembelajaran yang cocok dengan materi atau bahan ajaran.
Pendidikan jasmani olahraga dan kesehatan merupakan pelajaran yang sangat penting dalam dunia pendidikan untuk menjaga kebugaran peserta didik. PJOK yang diajarkan di satuan pendidikan nonformal penyelenggara pendidikan kesetaraan memiliki peran sangat penting, yaitu memberikan kesempatan kepada peserta untuk terlibat langsung dalam berbagai pengalaman belajar melalui aktivitas jasmani, olahraga dan kesehatan yang terpilih yang dilakukan secara sistematis. "Pendidikan jasmani olahraga dan kesehatan pada hakikatnya adalah pendidikan melalui aktivitas jasmani yang dijadikan sebagai media untuk mencapai perkembangan individu secara menyeluruh" (Suherman, 2000:1).

Jadi, PJOK merupakan bagian integral dari pendidikan secara menyeluruh dalam rangka memperoleh peningkatan bagi perkembangan individu yang melibatkan serta mengembangkan aspekaspek jasmani, intelektual, emosional, dan moral spiritual melalui aktivitas jasmani yang dilakukan secara sadar dan terprogram dalam usaha meningkatkan kemampuan dan keterampilan jasmani dan soaial serta perkembangan kecerdasan secara menyeluruh.

Menurut Schunk (dalam Susanto 2013) "motivasi adalah suatu proses diinisiasikannya dan dipertahankannya aktivitas yang diarahkan pada pencapaian tujuan". Adapun menurut Djamarah (2002:114), "motivasi adalah suatu pendorong yang mengubah energi dalam diri seseorang kedalam bentuk aktivitas nyata untuk mencapai tujuan tertentu". Sedangkan menurut Hamalik (dalam Saeful Rahmat, 2018: 139) menyatakan bahwa, "motivasi menunjukkan pada semua gejala yang terkandung dalam stimulus tindakan ke arah tujuan tertentu, yang sebelumnya belum ada gerakan menuju ke arah tujuan tertentu". 
Berdasarkan penjabaran di atas maka motivasi dapat diartikan sebagai stimulus yang mendorong suatu individu untuk melakukan aktivitas demi mencapai tujuan yang ingin dicapai. Sehingga dapat ditarik kesimpulan bahwa motivasi belajar adalah suatu stimulus yang mendorong suatu individu untuk melakukan aktivitas demi mencapai tujuan belajar yang dilakukan.namun dengan pelaksanaan pembelajaran secara online membuat berubahnya tingkat motivasi belajar peserta didik.

$$
\text { Istilah pembelajaran online }
$$
mengandung pengertian yang sangat luas, sehingga banyak pakar yang menguraikan tentang definisi online dari berbagai sudut pandang. Salah satu definisi yang cukup dapat diterima banyak pihak misalnya dari Darin E. Hartley (2001) yang menyatakan, "online merupakan suatu jenis belajar mengajar yang memungkinkan tersampaikan nyabahan ajar kepeserta didik dengan menggunakan media internet, intranet atau media jaringan komputer lain". Dalam Glossary of online Terms(Glossary, 2001)menyatakan suatu definisi yang lebih luas bahwa, "online adalah system pendidikan yang menggunakan aplikasi elektronik untuk mendukung belajar mengajar dengan media internet, jaringan computer maupun komputer standalone".

Dari beberapa definisi yang muncul dapat kita simpulkan bahwa system atau konsep pendidikan yang memanfaatkan teknologi informasi dalam proses belajar mengajar dapat disebut sebagai suatu pembelajaran online. Beragam istilah dan batasan telah dikemukakan oleh para ahli teknologi informasi dan pakar pendidikan. Secara sederhana online dapat dipahami sebagai suatu proses pembelajaran yang memanfaatkan teknologi informasi berupa komputer atau perangkat android yang dilengkapi dengan sarana telekomunikasi (internet, ekstranet) dan multimedia (grafis, audio, video) sebagai media utama dalam penyampaian materi dan interaksi antara pengajar (guru) dan pembelajar (peserta didik).

Model pembelajaran berbasis online berakibat pada perubahan budaya belajar dalam kontek pembelajarannya. Setidaknya ada empat komponen penting dalam membangun budaya belajar dengan menggunakan model online di sekolah. Pertama, peserta didik dituntut secara mandiri dalam belajar dengan berbagai pendekatan yang sesuai agar peserta didik mampu mengarahkan, memotivasi, mengatur dirinya sendiri dalam pembelajaran. Kedua, guru mampu mengembangkan pengetahuan dan ketrampilan, memfasilitasi dalam pembelajaran, memahami belajar dan halhal yang dibutuhkan dalam pembelajaran. Ketiga tersedianya infrastruktur yang memadaidan yang keempat administrator yang kreatif serta penyiapan infrastrukur dalam memfasilitasi pembelajaran.

Permasalahan yang dihadapi sekolah saat ini adalah pada tingkat kesiapan peserta belajar, guru, infrastruktur sekolah, pembiayaan, efektivitas pembelajaran, system penyelenggaraan dan daya dukung sekolah dalam menyelenggarakan pembelajaran berbasis online. Online Learning (pembelajaran secara langsung) menurut Michael Molinda (2005:182) dapat didefinisikan "sebagai upaya menghubungkan pembelajar (peserta didik) dengan sumber belajarnya (database, pakar/instruktur, perpustakaan) yang secara fisik terpisah atau bahkan berjauhan namun dapat saling berkomunikasi, berinteraksi atau berkolaborasi secara (secara langsung/synchronous dan secara tidak langsung/asynchronous)".

\section{METODE PENELITIAN}

Penelitian ini diklasifikasian kedalam penelitian eksperimen semu (kuasi eksperimen). Desain yang digunkan dalam penelitian ini adalah Posttes Only Control 
Group Design. Populasi penelitian adalah seluruh peserta didik kelas VIII SMPN 12 Denpasar dengan jumlah 437 orang, sementara kelas yang digunakan sebagai sampel penelitian adalah kelas VIII $F$ dengan jumlah 40 orang. Adapun variabel dalam penelitian ini ada 2, yaitu 1 variabel terikat (devenden variabel) dan 1 variabel bebas (indevenden variabel). Variabel terikat dalam penelitian ini adalah motivasi belajar peserta didik. Motivasi belajar yang dimaksud dalam penelitian ini adalah mengarah pada perilaku siswa untuk menuju ke arah atau tujuan tertentu yang dipengaruhi oleh faktor dari luar (ekstrinsik)dan faktor dari dalam(intrinsik). Proses pembelajaran dalam jaringan yang maksud adalah pembelajaran yang dilakukan dengan pemberian materi pembelajaran tanpa tatap muka,.

Pengumpulan data dilakukan sebanyak 1 tahap yaitu pengumpulan data motivasi belajar peserta didik. Metode pengumpulan data yang dilakukan dengan menggunakan angket kuisioner dan dokumentasi. Instrumen penelitian yang digunakan dalam penelitian ini adalah instrumen kuisioner motivasi belajar yang didukung dengan dokumentasi proses pengisian kuisioner. Kuisioner yang digunakan adalah kuisioner motivasi belajar PJOK di SMP, yang terdiri dari 30 butir, yang terbagi atas 20 pernyataan positif dan 10 pernyataan negatif. Kuisioner ini disajikan dalam bentuk skala likert dengan 4 alternatif jawaban mulai dari sangat tidak setuju, tidak setuju, setuju dan sanagat setuju. Untuk pensekoran skala likert, jawaban diberikan dengan nilai kumulatif mulai dari 4, 3, 2, 1 untuk pernyataan positif dan mulai dari 1, 2, 3, 4 untuk pernyataan negatif. Sebelum instrumen digunakan terlebih dahulu instrumen di uji coba.Uji coba yang dilakukan adalah uji validitas konstruk, uji validitas butir dan uji reabilitas tes. Penelitian ini menggunakan dua teknik analisis data yaitu analisis statistik deskriptif dan analisis korelasi sederhana. Analisis statistik deskriptif digunakan untuk menggambarkan motivasi belajar PJOK. Analisis korelasi digunakan untuk menentukan hubungan dan besarnya koefisien korelasi prediktif dengan kriterium.

\section{HASIL DAN PEMBAHASAN}

Data yang dicari sebagai hasil penelitian ini adalah data motivasi belajar PJOK pada saat proses pembelajaran dilaksanakan secara daring akibat dari merebaknya pandemi Covid-19. Data hasil penelitian dianalisis dengan statistik deskriptif. Sebelum data motivasi belajar PJOK siswa pada saat penerapan pembelajaran daring dianalisis, terlebih dahulu dimasukkan ke dalam tabel distribusi frekuensi berikut.

Tabel 1. Distribusi Distribusi frekuensi motivasi belajar PJOK pada saat penerapan pembelajaran daring.

\begin{tabular}{cccccc}
\hline Interval & $\begin{array}{c}\text { Batas Bawah } \\
\text { Kelas }\end{array}$ & $\begin{array}{c}\text { Nilai Tengah } \\
(\mathrm{X})\end{array}$ & $\begin{array}{c}\text { Frekwensi } \\
\text { Absolut }\left(f_{0}\right)\end{array}$ & $\begin{array}{c}\text { Frekwensi } \\
\text { Komulatif }\end{array}$ & $\mathrm{f}(\mathrm{X})$ \\
\hline $58-59$ & 57,5 & 58,5 & 4 & 4 & 234 \\
\hline $60-61$ & 59,5 & 60,5 & 5 & 9 & 302,5 \\
\hline $62-63$ & 61,5 & 62,5 & 8 & 17 & 500 \\
\hline $64-65$ & 63,5 & 64,5 & 12 & 29 & 774 \\
\hline $66-67$ & 65,5 & 66,5 & 6 & 35 & 399 \\
\hline $68-69$ & 67,5 & 68,5 & 5 & 40 & 342,5 \\
\hline & $\Sigma$ & & 40 & & 2552 \\
\hline
\end{tabular}


Dari tabel di atas, dapat ditentukan Mean (M), Median (Me) dan Modus (Mo). Sehingga Berdasarkan analisis statistikdeskriptif didapatkan nilai mean sebesar 63,8, median sebesar 64 dan modus sebesar 64,3 . Selain menentukan mean, median dan modus, dalam analisis statistik deskriptif juga ditentukan nilai varians dan standar deviasi. Dalam perhitungan yang dilakukan diperoleh varians sebesar 8,57 dan standar deviasi diperolrh sebesar 2,92.Mean, median dan modus selanjutnya disajikan ke dalam kurve poligon. Tujuan penyajian data ini adalah untuk menafsirkan sebaran data motivasi belajar PJOK pada saat diterapkan pembelajaran daring. Berikut ini data motivasi belajar PJOK pada saat diterapkan pembelajaran daring akan disajikan pada gambar1.

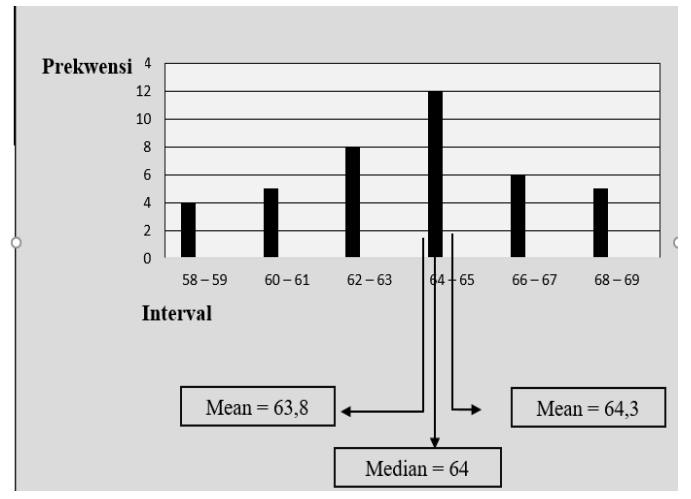

Gambar 1. Data sebaran motivasi belajar PJOK

Sementara itu bila dilihat dari distribusi nilai rata-rata motivasi belajar PJOK sebesar 63,8berada pada katagori rendah, hal ini dapat dibuktikan dengan membandingkan nilai rata-rata motivasi belajar PJOK dengan tabel skala skor motivasi belajar PJOK peserta didik berikut.

Tabel 2: Skala Skor Motivasi Belajar PJOK Siswa Pada Saat Penerapan Pembelajaran Daring.

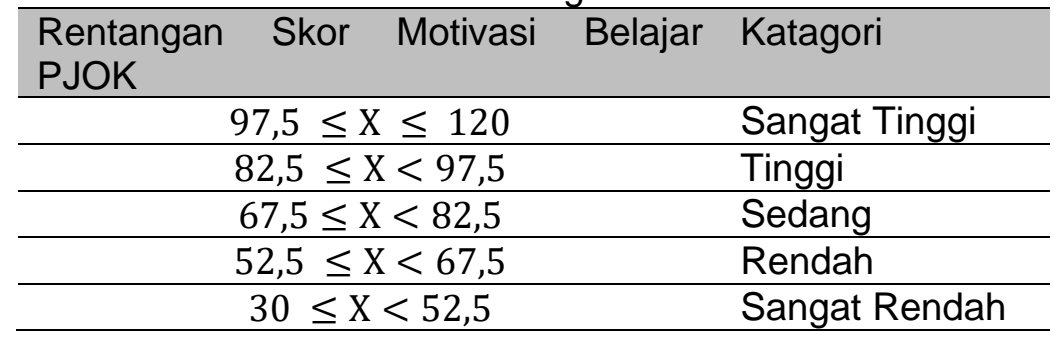

Selanjutnya dilakukan uji normalitas sebaran untuk mengetahui apakah data dalam penelitian memiliki distribusi normal atau tidak. Apabila sebaran data sudah berdistribusi normal, maka uji lanjut dengan menggunakan statistik parametrik bisa dilakukan. Sebaliknya, jika sebaran data tidak berdistribusi normal, maka tidak bisa dilakuakan uji lanjut menggunakan statistik parametrik, tetapi analisis masih bisa dilakukan dengan statistik non parametrik. Berdasarkan analisis yang dilakukan diperoleh hasil bahwa harga $x^{2}$ hitung = 6,474 . Sementara itu harga $x^{2}$ tabel adalah 7,815 dengan $\mathrm{dk}=$ jumlah kelas parameter $-1(\mathrm{dk}=6-2-1=3)$ dan taraf signifikansi 5\%. Jadi data motivasi belajar PJOk siswa pada saat penerapan pembelajaran daring berdistribusi normal karena nilai $x^{2}$ hitung $<x^{2}$ tabel $(6,474<$ $7,815)$.

Setelah data dinyatakan normal selanjutnya dilakukan uji hipotesis dengen mengajukan hipotesis berikut

$H_{0}=$ tidak terdapat dampak pandemi covid-19 terhadap motivasi belajar daring mata PJOK

$H_{a}=$ terdapat dampak pandemi covid-19 terhadap motivasi belajar daring mata PJOK 
Berdasarkan analisis statistik deskriptif yang akan digunakan untuk menguji hipotesis, maka hipotesis $H_{a}$ diterima sehingga hasil penelitian dapat disimpulkan, bahwa terdapat dampak pandemi covid-19 terhadap motivasi belajar daring mata PJOK. Dampak yang dihasilkan adalah lebih rendahnya motivasi belajar PJOK peserta didik karena penerapan pembelajaran daring dari dampak pandemi covid-19.

\section{PEMBAHASAN}

Penelitian dilakukan di kelas VIII SMP Negeri 12 Denpasar. Kelas VIII SMP Negeri 12 Denpasar terdiri dari 11 kelas dengan jumlah siswa sebanyak 439. Penelitian dilakukan tentang dampak pandemi covid-19 terhadap motivasi belajar PJOK. Berdasarkan hasil perhitungan yang dilakukan didapatkan rata-rata motivasi belajar PJOK peserta didik pada saat penerapan pembelajaran daring sebesar 63,8. Sementara itu bila dilihat dari distribusi nilai rata-rata motivasi belajar PJOK pada saat penerapan pembelajaran daring berada pada katagori rendah. Dengan demikian dapat ditarik kesimpulkan berdasarkan pengujian hipotesis berarti terdapat dampak pembelajaran daring terhadap motivasi belajar PJOK peserta didik.

Pembelajaran dilaksanakan dengan pembelajaran secara daring maka proses pembelajaran dilaksanakan secara jarak jauh karena dalam pembelajaran secara daring merupakan system atau konsep pendidikan yang memanfaatkan teknologi informasi dalam proses belajar mengajar yang dapat disebut sebagai suatu pembelajaran online. Secaras ederhana online dapat dipahami sebagai suatu proses pembelajaran yang memanfaatkan teknologi informasi berupa komputer atau perangkat android yang dilengkapi dengan sarana telekomunikasi (internet, ekstranet) dan multimedia (grafis, audio, video) sebagai media utama dalam penyampaian materi dan interaksi antara pengajar (guru) dan pembelajar (peserta didik).

Model pembelajaran berbasis online berakibat pada perubahan budaya belajar dalam kontek pembelajarannya. Setidaknya ada empat komponen penting dalam membangun budaya belajar dengan menggunakan model online di sekolah. Pertama, peserta didik dituntut secara mandiri dalam belajar dengan berbagai pendekatan yang sesuai agar peserta didik mampu mengarahkan, memotivasi, mengatur dirinya sendiri dalam pembelajaran. Kedua, guru mampu mengembangkan pengetahuan dan ketrampilan, memfasilitasi dalam pembelajaran, memahami belajar dan halhal yang dibutuhkan dalam pembelajaran. Ketiga tersedianya infrastruktur yang memadai dan yang ke empat administrator yang kreatif serta penyiapan infrastrukur dalam memfasilitasi pembelajaran.

Keberagaman kesiapan sarana dan mental bagi pembelajaran online di Indonesia bervariatif. Dengan demikian pembelajaran jarak jauh online saat ini, tidak etis jika kita mengharuskan untuk mengadakan evaluasi yang tersistem berskala nasional. Justru yang paling penting bagi dunia pendidikan adalah pentingnya menunjukkan keberlangsungan proses pembelajaran. Dengan demikian bagi insan yang bergelut di dunia pendidikan, harus bersama-sama bersatu tekad untuk menjalankan proses pembelajaran online secara bertanggungjawab, bijak dalam mengambil keputusan, dan yang paling penting, selalu bersama dengan anak didik dalam memahami keberadaannya sebagai makhluk yang punya jiwa, harap, dan asa. Karena tantangan pembelajaran online yang tidak bertatap muka secara langsung adalah cenderung mengevaluasi dengan menitikberatkan pada penguatan hasil yang mengabaikan rasa. 
Jadi sekalipun ada model online, insane pendidik sebagai kunci keberhasilan proses pembelajaran perlu memperlengkapi dengan menggunakan aplikasi sepert iwhatsapp atau line yang cepat informasinya untuk menyapa anak didiknya seperti selayaknya di dalam kelas meskipun dalam dunia virtual. Sehingga ikatan rasa anak didik dan juga pendidik sendiri terkelola Secara baik. Untuk itu kedepan pembelajaran online atau daring (dalam jaringan) di Indonesia masih perlu mendapat perhatian dan perlu ditingkatkan baik dari segi sarana prasarana maupun dalam pengaplikasiannya agar mampu bersaing dalam lajunya globalisasi.

\section{SIMPULAN DAN SARAN}

Berdasarkan hasil analisis data dan pembahasan, dapat ditarik kesimpulan bahwa, rata-rata motivasi belajar PJOK pada saat penerapan pembelajaran daring sebesar 63,8 . Sementara itu bila dilihat dari distribusi nilai rata-rata motivasi belajar PJOK pada saat penerapan pembelajaran daring berada pada katagori rendah, hal ini dapat dibuktikan dengan membandingkan nilai rata-rata motivasi belajar PJOK dengan tabel skala skor motivasi belajar PJOK peserta didik. Sehingga Berdasarkan hasil analisis yang dilakukan maka, pembelajaran daring berdampak pada motivasi belajar PJOK, dampak yang diakibatkan adalah motivasi belajar peserta didik menjadi lebih rendah pada saat pembelajaran daring.

Disarankan kepada guru PJOK, dalam meningkatkan motivasi belajar peserta didik hendaknya guru lebih sering melaksanakan pembelajaran secara tatap muka, memberikan contoh-contoh dalam melaksanakan praktek pembelajaran dan menggunakan media-media pembelajaran yang menarik yang mampu memancing antusias peserta didikdalam pelaksanaan pembelajaran.Bagi sekolah dapat dijadikan sebagai pedoman dan acuan dalam penerapan pembelajaran daring, dan memberikan sarana pendukung yang tepat sehingga guru mampu berkreativitas lebih dalam pengembangan pembelajaran daring.Diharapkan kepada siswa-siswa yang dijadikan subjek penelitian selanjutnya lebih memperhatikan dan memahami pembelajaran yang diberikan, agar dapat menambah wawasan pengetahuan. Dan bagi calon peneliti yang berminat untuk eneliti lebih lanjut tentang tingkat motivasi belajar daring akibat dampak pandemi covid-19, hendaknya mempertimbangkan faktor-faktor lain yang mungkin mempengaruhi proses dan hasil penelitian.

\section{DAFTAR PUSTAKA}

Agung, A. A. Gede. 2010. Pengantar IImu Pendidikan. Singaraja: Jurusan Teknologi Pendidikan Fakultas IImu Pendidikan Universitas Pendidikan Ganesha.

------, A. A. Gede. 2011. Metodelogi Penelitian Pendidikan. Singaraja: Fakultas IImu Pendidikan Universitas Pendidikan Ganesha.

Aqib, Zainal dan Rasidi, Mohammad Hasan. 2010. Metodologi Penelitian Pendidikan. Yogyakarta: Andi Yogyakarta.

Arikunto, Suharsimi. 2010. Prosedur Penelitian Suatu Pendekatan Praktik. Jakarta: PT. Rineka Cipta

Baharudin, dkk. 2020. Janagan Takut Pada Corona.Jakart

B. Uno, Hamzah. 2007. Teori motivasi dan Pengukuran. Jakarta: Bumi Aksara.

Candiasa, I. M. 2010. Pengujian instrumwn Penelitian DisertaiAplikasi Iteman dan Bigsteps. Singaraja: Unit Penerbitan Universitas Pendidikan Ganesha.

Darin E. Hartley. 2001. Selling E-Learning. American Society for Training and Development. 
Depdiknas. 2004. Badan Standar Nasional Pendidikan. Jakarta: Dapertemen Pendidikan Nasional.

Depdiknas. 2006. Kurikulum KTSP. Jakarta: BSNP.

Dimyati dan Mujijono. 2006. Belajar dan Pembelajaran. Jakarta: Rineka Cipta.

Djamarah, S. B. 2002. Strategi Belajar Mengajar. Jakarta: Rineka Cipta

Hamalik, Oemar.2001. Proses Belajar Mengajar. Cetakan Pertama. Jakarta : Pt Bumi Aksara.

I Putu Budiariawan. 2019. Hubungan Motivasi Belajar Pada Mata Pelajaran Kimia Dengan Hasil Belajar Kimia Peserta didik SMA Negeri 2 Negara. Singaraja: Skripsi Undiksha Singaraja.

Koyan, I Wayan. 2009. Buku Ajar Statistik Dasardan Lanjut (Teknik Analisis Kata Kuantitatif). Singaraja: Undiksha.

Michael Molinda. 2005. Instrucsional Technology and Media for Learning New Jersey Colombus. Ohio.

Nana Syaodih Sukmadinata. 2005. Metode Penelitian Pendidikan. Bandung: Remaja Rosda Karya

Ni Komang Sri Pustika Dewi. 2017. Pengaruh Efikasi diri Terhadap Motivasi dan Prestasi Belajar Peserta didik Kelas XI IPA Pada Pembelajaran Fisika Di SMA Negeri 1 Sawan. Laporan Pelitian (tidak diterbitkan): Skripsi Undiksha Singaraja.

Kanca, I Nyoman. 2010. MetodePenelitianPengajaranPendidi kanJasmani dan Olahraga. Singaraja: Undiksha.

Putu Adi Arimbawa. 2017. Strategi Pembelajaran Guru fisika: Relevansinya Dalam Pengembangan Motivasi Belajar Dan Prestasi Belajar Fisika Peserta didik Kelas X MIA 3 Di SMA Negeri 7 Denpasar. Laporan Pelitian (tidak diterbitkan): Skripsi Undiksha Singaraja.

Rahmat, Pupu Saeful. 2018. Psikologi Pendidikan. Jakarta : Bumi Aksara.

Sadirman. 2007. Interaksi dan Motifasi Belajar Mengajar. Jakarta: Raja Grafindo Persada.

2008. Interaksi dan Motivasi Belajar Mengajar. Jakarta: PT raja Grafindo Persada.

Sugiyono. 2009. Metode Penelitian Kuantitatif, Kualitatifdan R\&D. Bandung: Alfabeta.

------. 2010. Statistik Untuk Penelitian. Bandung: Alfabeta. 2014. Statistik Untuk Penelitian.

Bandung: Alfabeta.

Susanto, Ahmad. 2013. Teori Belajar \& Pembelajaran di Sekolah Dasar. Jakarta: Prenadamedia Grup.

Usman, Moh. Uzer. 2001. Penilaian Hasil Proses Belajar Mengajar. Bandung: Remaja Rosdakarya 